\title{
Molecular and Crystal Structure of Spiculisporic Acid and Correlation with the Surface Activity
}

\author{
Yutaka Ishigami ${ }^{1 *}$, Yuejun Zhang ${ }^{1}$ and Midori Goto ${ }^{2}$ \\ ${ }^{1}$ School of Chemical Engineering, Nanjing University of Science and Technology (200 Xiao Lin Wei, Nanjing 210094, P.R. CHINA) \\ ${ }^{2}$ Technical Center, National Institute of Advanced Industrial Science and Technology (Central 5, 1-1-1 Higashi, Tsukuba, Ibaraki 305-8566, \\ JAPAN)
}

\begin{abstract}
The crystal of spiculisporic acid, [4S, 5S-(4,5-dicarboxy-4-pentadecanolide)], is orthorhombic, and the space group is $P 2_{1} 2_{1} 2_{1}$ with $Z=4$ at $23^{\circ} \mathrm{C}$. The cell dimensions are as follows, $a=43.82$ (1) $\AA, b=7.540$ (2) $\AA, c=5.579$ (2) $\AA, V=1843$ (1) $\AA^{3}$. The molecules form intermolecular networks linked by hydrogen bonds around their polar carboxylic moieties. The hydrophobicity of the lactone ring ( $\gamma$-butanolide) was evaluated at ca. 4 methylene linkages of $n$-alkyl chain from both of the molecular alignmental data and the surface active properties of sodium spiculisporates. Then, it was made clear that sodium spiculisporates, anionic polyfunctional biosurfactants, exerted a distinctive characteristic of lower critical micelle concentration (cmc) and $\gamma_{\mathrm{cmc}}$ (surface tension at the $\mathrm{cmc}$ ), simultaneously, through their properties. On the other hand, sodium salts of the lactone-cleaved derivative of spiculisporic acid (O-acid), showed large dispersing and calcium ion sequestration properties due to their plural polar heads.
\end{abstract}

Key words: spiculisporic acid, anionic biosurfactant, X-ray crystallographic analysis, hydrophobicity of lactone ring, Hartley effect

\section{INTRODUCTION}

Goto et al. ${ }^{1-3)}$ reported crystal structures of long-chain fatty acids, monoacyl glycerol, and triglycerides. The crystal structures were specific because of the space-filling crystal packing necessary for the hydrophobic long alkyl chains and bulky terminal heads. Surfactant molecules have similar chemical structures to them, and their crystal packing has been investigated ${ }^{4,5)}$. The present authors have also reported on the crystal structures for curcumin ${ }^{6)}$ and $n$-heptyl $\beta$-D-xyloside ${ }^{7)}$ as the amphiphiles from biological origins. Spiculisporic acid (abbreviated as S-acid below) is a microbial biosurfactant with a unique long chain fatty acid carrying two carboxylic moieties and a lactone ring $(\gamma \text {-lactone })^{8-11)}$. Both S-acid and its lactone ringcleaved derivative (O-acid below) have the cloud points at ca. $85^{\circ} \mathrm{C}$ and $44^{\circ} \mathrm{C}$, respectively ${ }^{12)}$. S-acid and O-acid are able to lower the points by their neutralization with alkalis like carboxylic-type anionic surfactants ${ }^{9-11)}$.

Otherwise, Microbially produced surfactin, a lipopeptidetype biosurfactant, is a kind of macrocyclic-lactone derivative, and formed rod-shaped micelles organized in $\beta$-sheet conformation from $\alpha$-helix monomers despite of macrocyclic- and linear-type ones ${ }^{13,14)}$. Microbially produced biosur- factant, lactonic sophorolipid (major constituent of sophorolipids) is also a multifunctional and green-chemical surfactant $^{15-17)}$. Spiculisporic acid is nontoxic in the environment ${ }^{18)}$, and has anti-oxidative stress actions in biological systems by means of the yeast DNA microarray bioassay $^{19)}$. However, there are no investigations about the role of the $\gamma$-butanolide (lactone ring) in the solution properties of $\gamma$-lactone carrying surfactants. This paper treats the molecular and crystal structure of S-acid and its relation to the properties of aqueous sodium spiculisporates solutions in focusing on the hydrophobicity of the lactone ring ( $\gamma$-butanolide).

\section{EXPERIMENTAL}

\subsection{Materials}

Spiculisporic acid [4S, 5S- (4,5-dicarboxy-4-pentadecanolide) ] was produced from glucose as the sole carbon source in the culture broth of Penicillium spiculisporum ${ }^{12,20)}$, and was supplied from Iwata Chemical Co., Ltd. (Iwata, Shizuoka Japan). The needle-like white crystal of spiculisporic acid was obtained by repeating recrystallization

\footnotetext{
*Correspondence to: Yutaka Ishigami, School of Chemical Engineering, Nanjing University of Science and Technology, 200 Xiao Lin Wei, Nanjing 210094, P. R. CHINA

E-mail: fwkk0015@mb.infoweb.ne.jp

Accepted April 15, 2013 (received for review February 14, 2013)

Journal of Oleo Science ISSN 1345-8957 print / ISSN 1347-3352 online

http://www.jstage.jst.go.jp/browse/jos/ http://mc.manusriptcentral.com/jjocs
} 
from ethanol.

On the addition of the equimolar $\mathrm{NaOH}$ in normalized solutions to S-acid at a room temperature of around $20^{\circ} \mathrm{C}$, mono-sodium salt of S-acid (abbreviated as $\mathrm{S}-1 \mathrm{Na}$ ) and double molar addition, S-2Na, were produced. The lactone ring of S-acid was cleaved by heating with triple-molar $\mathrm{NaOH}$ at $70^{\circ} \mathrm{C}$, and the resultant tri-sodium salt of spiculisporic acid was neutralized with triple-molar $\mathrm{HCl}$ in order to convert to O-acid. Then, O-acid was extracted with ethanol from the resultant precipitate. The chemical struc- ture of O-acid, $(4 S, 5 S)$-3-hydroxy-1,3,4-tetradecanetricarboxylic acid, was confirmed with the elemental and IR analyses ${ }^{8)}$. Then, O-acid was neutralized with the equimolar $\mathrm{NaOH}$ to get mono-sodium salt of $\mathrm{O}-\operatorname{acid}(\mathrm{O}-1 \mathrm{Na})$, and disodium salt of $\mathrm{O}$-acid $(\mathrm{O}-2 \mathrm{Na})$ with double molar one, and tri-sodium salt of $\mathrm{O}$-acid $(\mathrm{O}-3 \mathrm{Na})$ with triple molar one ${ }^{9)}$.

\subsection{Methods}

A single crystal of $(4 S, 5 S)$-4,5-dicarboxy-4-pentadecanolide, $0.1 \times 0.15 \times 0.8 \mathrm{~mm}$, was selected for X-ray mea-

Table 1 Crystal data and summary of experimental details.

\begin{tabular}{|c|c|c|}
\hline \multicolumn{3}{|l|}{ Crystal data: } \\
\hline \multicolumn{2}{|l|}{ Molecular formula } & $\mathrm{C}_{17} \mathrm{O}_{6} \mathrm{H}_{28}$ \\
\hline \multicolumn{2}{|l|}{ M.W. } & 328.54 \\
\hline \multirow{2}{*}{\multicolumn{2}{|c|}{ M.P. }} & $132^{\circ} \mathrm{C},[\alpha]_{\mathrm{D}}^{26}=-12.6$ \\
\hline & & $(\mathrm{C}=3.28 \mathrm{~g} / \mathrm{dl}$, Ethanol $)$ \\
\hline \multicolumn{2}{|l|}{ Crystal system } & orthorhombic \\
\hline \multicolumn{2}{|l|}{ Space group } & $\mathrm{P} 2_{1} 2_{1} 2_{1}$ \\
\hline \multicolumn{2}{|l|}{$\mathrm{Z}$} & 8 \\
\hline \multirow[t]{4}{*}{ Lattice parameters } & $\mathrm{a}$ & $43.82(1) \AA$ \\
\hline & $\mathrm{b}$ & $7.540(2) \AA$ \\
\hline & $\mathrm{c}$ & $5.579(2) \AA$ \\
\hline & $\mathrm{V}$ & $1843(1) \AA^{3}$ \\
\hline \multicolumn{2}{|l|}{ Dcalc } & $1.17 \mathrm{~g} / \mathrm{cm}^{3}$ \\
\hline \multicolumn{2}{|l|}{$\mu(\operatorname{MoK} \alpha)$} & $0.827 \mathrm{~cm}^{-1}$ \\
\hline \multicolumn{3}{|l|}{ Data collection: } \\
\hline \multicolumn{2}{|l|}{ Radiation } & $\operatorname{MoK} \alpha$ \\
\hline \multicolumn{2}{|l|}{ Scan mode } & $2 \theta-\omega$ \\
\hline \multicolumn{2}{|l|}{ Temperature } & $23^{\circ} \mathrm{C}$ \\
\hline \multicolumn{2}{|l|}{ Scan mode } & $(1.10+0.30 \tan \theta)^{\circ}$ \\
\hline \multicolumn{2}{|l|}{ Scan speed } & $8 \% / \min$ \\
\hline \multicolumn{2}{|l|}{$2 \theta \max$} & $55^{\circ}$ \\
\hline \multicolumn{2}{|l|}{ No. of Reflection Measured } & 2621 \\
\hline \multicolumn{2}{|l|}{ Corrections } & Lorentz-polarization \\
\hline \multicolumn{3}{|l|}{ Structure Solution and Refinement: } \\
\hline \multicolumn{2}{|l|}{ Structure Solution } & SIR92 \\
\hline \multicolumn{2}{|l|}{ Refinement } & Full-matrix least squares on $\mathrm{F}$ \\
\hline \multicolumn{2}{|l|}{ Number of observed reflections (I > $2.0 \sigma(\mathrm{I}))$} & 1391 \\
\hline \multicolumn{2}{|l|}{ R1-Factor } & 0.052 \\
\hline \multicolumn{2}{|l|}{ RW-Factor } & 0.086 \\
\hline \multicolumn{3}{|c|}{$\mathrm{W}=1 / \operatorname{sig} * * 2(\mathrm{Fo})$} \\
\hline \multicolumn{2}{|l|}{$\mathrm{S}$} & 0.8 \\
\hline \multicolumn{2}{|l|}{ Maximum peak in final Diff. Map } & $0.19 \mathrm{e} \AA^{3}$ \\
\hline \multicolumn{2}{|l|}{ Minimum peak in final Diff. Map } & -0.23 e $\AA^{3}$ \\
\hline
\end{tabular}


surement. The lattice constant and intensity data were measured at $23^{\circ} \mathrm{C}$ on a Mac Science MXC18K 4-circle diffractometer with graphite-monochromated MoKa radiation. The structure was solved by direct methods with SIR92 ${ }^{21)}$. Crystal data, details of data collections, and refinement results are given in Table 1. The calculation were performed using Crystan-GM ${ }^{22}$. The final refinement was carried out by the full-matrix least squares method using anisotropic temperature factors for the non-hydrogen atoms. Hydrogen atoms attached to the hydroxyl groups could not be found by the Differential Fourier synthesis, and were omitted. Other hydrogen atoms were located by geometric considerations and refined as riding on their carried carbon atoms. The other measurements were described elsewhere ${ }^{8,9)}$.

\section{RESULTS and DISCUSSION}

\subsection{Crystal Structure of Spiculisporic Acid}

The crystal data and the final atomic parameters are listed in Table 1. The fractional atomic coordinates and thermal parameters are listed in Table 2. The selected bond lengths and angles are given in Tables 3-1 and 3-2. The molecular structure and the atomic numberings are represented in Fig. 1. The molecule forms in an all-trans conformation from $\mathrm{C}(4)$ to $\mathrm{C}(15)$. The two carboxylic moieties are branched from $\mathrm{C}(4)$ to $\mathrm{C}(16), \mathrm{O}(3), \mathrm{O}(4)$, and from $\mathrm{C}(5)$ to $\mathrm{C}(17), \mathrm{O}(5), \mathrm{O}(6)$, respectively. The lactone ring ( $\gamma$-butanolide) consists of $\mathrm{O}(1)-\mathrm{C}(1)-\mathrm{C}(2)-\mathrm{C}(3)-\mathrm{C}(4)$. The dihedral angle between $n$-undecyl chain and the lactone ring is almost $137^{\circ}$.

The crystal packing along the b-axis is shown in Fig. 2. The molecules stack along the b-axis, and the alkyl chains form an interdigitated alignment from molecule to molecule by the interpenetration of adjacent alkyl chains. The crystal packing along the c-axis is also shown in Fig. 3. The two molecules connected by two carboxylic moieties per

Table 2 Fractional atomic coordinates and thermal parameters (non-hydrogen atoms).

\begin{tabular}{ccrrr}
\hline atom & $x$ & $y$ & \multicolumn{1}{c}{$z$} & $\mathrm{U}$ (iso) \\
\hline $\mathrm{O}(1)$ & $0.71077(7)$ & $0.2729(5)$ & $0.0760(6)$ & 0.039 \\
$\mathrm{O}(2)$ & $0.75998(9)$ & $0.2915(8)$ & $-0.0136(9)$ & 0.072 \\
$\mathrm{O}(3)$ & $0.69458(10)$ & $-0.0520(5)$ & $0.1026(9)$ & 0.063 \\
$\mathrm{O}(4)$ & $0.66858(9)$ & $-0.0232(5)$ & $0.4431(8)$ & 0.057 \\
$\mathrm{O}(5)$ & $0.66016(10)$ & $0.6198(5)$ & $0.4586(8)$ & 0.060 \\
$\mathrm{O}(6)$ & $0.68072(11)$ & $0.6116(5)$ & $0.1021(9)$ & 0.066 \\
$\mathrm{C}(1)$ & $0.74061(11)$ & $0.2714(7)$ & $0.1346(13)$ & 0.051 \\
$\mathrm{C}(2)$ & $0.74434(12)$ & $0.2472(9)$ & $0.3961(13)$ & 0.057 \\
$\mathrm{C}(3)$ & $0.71207(12)$ & $0.2760(9)$ & $0.4989(11)$ & 0.047 \\
$\mathrm{C}(4)$ & $0.69202(9)$ & $0.2354(6)$ & $0.2804(9)$ & 0.033 \\
$\mathrm{C}(5)$ & $0.66210(9)$ & $0.3408(6)$ & $0.2648(10)$ & 0.037 \\
$\mathrm{C}(6)$ & $0.64427(10)$ & $0.2970(8)$ & $0.0361(11)$ & 0.043 \\
$\mathrm{C}(7)$ & $0.61283(12)$ & $0.3860(9)$ & $0.0267(13)$ & 0.051 \\
$\mathrm{C}(8)$ & $0.59350(12)$ & $0.3216(10)$ & $-0.1830(13)$ & 0.057 \\
$\mathrm{C}(9)$ & $0.56164(12)$ & $0.4019(10)$ & $-0.1892(13)$ & 0.053 \\
$\mathrm{C}(10)$ & $0.54223(13)$ & $0.3270(10)$ & $-0.3911(14)$ & 0.060 \\
$\mathrm{C}(11)$ & $0.51008(14)$ & $0.4034(10)$ & $-0.3997(15)$ & 0.058 \\
$\mathrm{C}(12)$ & $0.49071(13)$ & $0.3215(11)$ & $-0.5966(13)$ & 0.058 \\
$\mathrm{C}(13)$ & $0.45814(13)$ & $0.3981(10)$ & $-0.6105(16)$ & 0.058 \\
$\mathrm{C}(14)$ & $0.43966(14)$ & $0.3167(11)$ & $-0.8113(17)$ & 0.070 \\
$\mathrm{C}(15)$ & $0.40703(17)$ & $0.3898(12)$ & $-0.8248(21)$ & 0.100 \\
$\mathrm{C}(16)$ & $0.68431(10)$ & $0.0355(7)$ & $0.2764(10)$ & 0.041 \\
$\mathrm{C}(17)$ & $0.66853(10)$ & $0.5383(7)$ & $0.2750(10)$ & 0.040 \\
\hline & & & &
\end{tabular}


Table 3-1 Intramolecular bond lengths ( $)$.

\begin{tabular}{|c|c|c|c|}
\hline $\mathrm{O}(1)-\mathrm{C}(1)$ & $1.348(6)$ & $\mathrm{O}(1)-\mathrm{C}(4)$ & $1.434(6)$ \\
\hline $\mathrm{O}(2)-\mathrm{C}(1)$ & $1.195(8)$ & $\mathrm{O}(3)-\mathrm{C}(16)$ & $1.256(8)$ \\
\hline $\mathrm{O}(4)-\mathrm{C}(16)$ & $1.239(7)$ & $\mathrm{O}(5)-\mathrm{C}(17)$ & $1.250(7)$ \\
\hline $\mathrm{O}(\mathrm{6})-\mathrm{C}(17)$ & $1.234(8)$ & $C(1)-C(2)$ & $1.479(10)$ \\
\hline $\mathrm{C}(2)-\mathrm{C}(3)$ & $1.542(8)$ & $\mathrm{C}(3)-\mathrm{C}(4)$ & $1.534(8)$ \\
\hline$C(4)-C(5)$ & $1.536(6)$ & $C(4)-C(16)$ & $1.545(7)$ \\
\hline$C(5)-C(6)$ & $1.532(8)$ & $\mathrm{C}(5)-\mathrm{C}(17)$ & $1.516(7)$ \\
\hline$C(6)-C(7)$ & $1.533(8)$ & $\mathrm{C}(7)-\mathrm{C}(8)$ & $1.524(10)$ \\
\hline $\mathrm{C}(\mathrm{8})-\mathrm{C}(9)$ & 1.522 & $\mathrm{C}(9)-\mathrm{C}(10)$ & $1.520(10)$ \\
\hline C (10)-C (11) & 1.523 (9) & $\mathrm{C}(11)-\mathrm{C}(12)$ & $1.519(11)$ \\
\hline C (12)-C (13) & $1.542(9)$ & C (13)-C (14) & $1.512(12)$ \\
\hline C (14)-C (15) & $1.534(11)$ & & \\
\hline
\end{tabular}

Table 3-2 Intramolecular bond angles $\left({ }^{\circ}\right)$.

\begin{tabular}{|c|c|c|c|}
\hline $\mathrm{C}(1)-\mathrm{O}(1)-\mathrm{C}(4)$ & $111.2(5)$ & $\mathrm{O}(1)-\mathrm{C}(1)-\mathrm{O}(2)$ & $121.4(7)$ \\
\hline $\mathrm{O}(1)-\mathrm{C}(1)-\mathrm{C}(2)$ & $110.3(5)$ & $\mathrm{O}(2)-\mathrm{C}(1)-\mathrm{C}(2)$ & $128.3(6)$ \\
\hline$C(1)-C(2)-C(3)$ & $104.4(5)$ & $C(2)-C(3)-C(4)$ & $101.6(5)$ \\
\hline $\mathrm{O}(1)-\mathrm{C}(4)-\mathrm{C}(3)$ & $105.4(4)$ & $\mathrm{O}(1)-\mathrm{C}(4)-\mathrm{C}(5)$ & $110.0(4)$ \\
\hline $\mathrm{O}(1)-\mathrm{C}(4)-\mathrm{C}(16)$ & $107.8(4)$ & $C(3)-C(4)-C(5)$ & $115.5(5)$ \\
\hline$C(3)-C(4)-C(16)$ & $109.4(5)$ & $C(5)-C(4)-C(16)$ & $108.5(4)$ \\
\hline$C(4)-C(5)-C(6)$ & $111.8(5)$ & $C(4)-C(5)-C(17)$ & $110.3(4))$ \\
\hline$C(6)-C(5)-C(17)$ & $109.8(5)$ & $C(5)-C(6)-C(7)$ & $113.1(5)$ \\
\hline $\mathrm{C}(6)-\mathrm{C}(7)-\mathrm{C}(8)$ & $112.7(6)$ & $\mathrm{C}(7)-\mathrm{C}(8)-\mathrm{C}(9)$ & $113.6(6)$ \\
\hline $\mathrm{C}(\mathrm{8})-\mathrm{C}(9)-\mathrm{C}(10)$ & $112.5(6)$ & $\mathrm{C}(9)-\mathrm{C}(10)-\mathrm{C}(11)$ & $113.6(7)$ \\
\hline C (10)-C (11)-C (12) & $112.7(7)$ & $\mathrm{C}(11)-\mathrm{C}(12)-\mathrm{C}(13)$ & $113.6(7)$ \\
\hline C (12)-C (13)-C (14) & $112.4(7)$ & C (13)-C (14)-C (15) & $112.9(8)$ \\
\hline $\mathrm{O}(3)-\mathrm{C}(16)-\mathrm{O}(4)$ & $126.2(5)$ & $\mathrm{O}(3)-\mathrm{C}(16)-\mathrm{C}(4)$ & $116.4(5)$ \\
\hline $\mathrm{O}(4)-\mathrm{C}(16)-\mathrm{C}(4)$ & $117.3(5)$ & $\mathrm{O}(5)-\mathrm{C}(17)-\mathrm{O}(6)$ & $123.2(5)$ \\
\hline $\mathrm{O}(5)-\mathrm{C}(17)-\mathrm{C}(5)$ & $117.4(5)$ & $\mathrm{O}(6)-\mathrm{C}(17)-\mathrm{C}(5)$ & $119.4(5)$ \\
\hline
\end{tabular}



Fig. 1 Drawing of the molecular structure of spiculisporic acid obtained by the X-ray crystallographic analysis.

molecule owing to their hydrogen bonds, and all molecules completely join the network formation. The dihedral angle of chains 1) and 4) is almost perpendicular, $90.7^{\circ}$ in Fig. 2, for 1 ) and 2), the angle is $140.6^{\circ}$ in Fig. 3. In a mesogenic

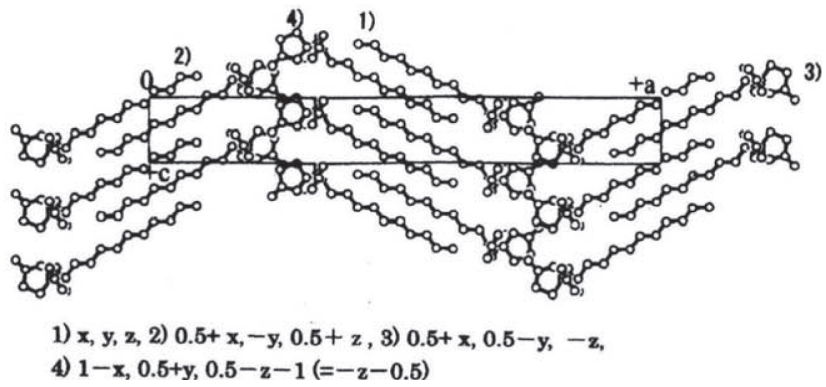

Fig. 2 Crystal packing of spiculisporic acid along the b-axis.

moiety, the dihedral angle between the lactone ring and the plane of the hydrogen bond ring is $88^{\circ}$ as shown in Fig. 4 , and the 4- and 5-position carboxylic moieties are located 


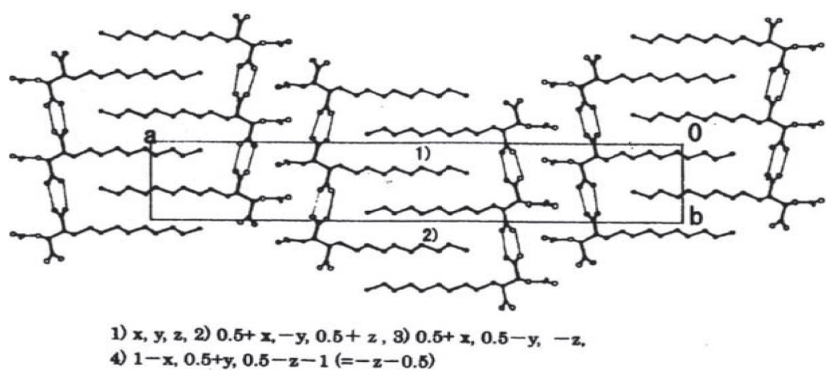

Fig. 3 Crystal packing of spiculisporic acid along the c-axis.

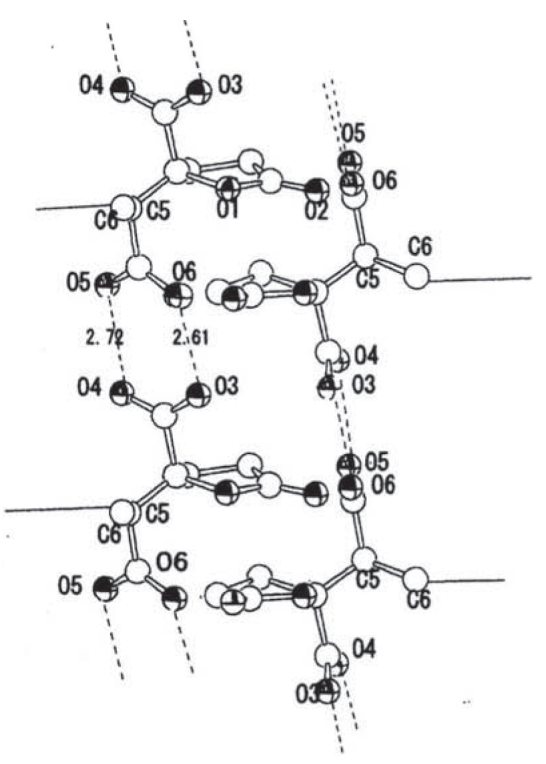

Fig. 4 The detail of the intermolecular network of hydrogen bonds among the polar carboxylic heads of spiculisporic acid.

in opposite directions in the alkyl chain(Fig. 4). The molecules are arranged in a layer structure from the lactone ring, and adjacent 4- and 5- position carboxylic moieties act as the origin.

Hydrogen bonds between the molecules are identified by the interatomic distances. Intermolecular hydrogen bonds between adjacent carboxylic moieties make an important role in stabilizing the lactone moiety for the space-filling crystal packing (Fig. 4). The molecules are linked by hydrogen bonds each other in the scheme of $\mathrm{O}(3)--\mathrm{O}(6)$ : $2.61 \AA$; O (4)---O (5): $2.72 \AA$. As an overall estimate, this basic structure forms an intermolecular network like that seen in Fig. 4. In detail, $\mathrm{O}(3)$ or $\mathrm{O}(6)$ of the carboxylic moiety links with $\mathrm{O}(4)$ or $\mathrm{O}(5)$ of the adjoining molecules, respectively.

\subsection{Correlation of the structures of sodium spiculispo- rates with their surface activities}

3.2.1 Geometric estimation for the hydrophobic contribution of the lactone ring ( $\gamma$-butanolide) of spiculisporic acid

The experimental results which showed smaller critical micelle concentrations $(\mathrm{cmc})$ and lower surface tension values at the $\mathrm{cmc}\left(\gamma_{\mathrm{cmc}}\right)$ values of $\mathrm{S}-1 \mathrm{Na}($ or S-2Na) than those of $\mathrm{O}-1 \mathrm{Na}$ (or O-2Na), are distinctive features. These results are summarized in Table $4^{8,9)}$. Furthermore, both of $\mathrm{cmc}$ and $\gamma_{\mathrm{cmc}}$ values of S-1Na are lower than those of S-2Na. These facts led to the conclusion that the lactone ring ( $\gamma$-butanolide) is a kind of hydrophobic moiety. The spacial length of the lactone ring is $3.4 \AA$ by measuring the distance between $\mathrm{C}(4)$ to $\mathrm{O}(2)$ (center-to-center) in Fig. 5. This was illustrated in an outline on the basis of Fig. 1, Fig. 2, Table 3-1, and Table 3-2. The length (3.4 $)$ is equivalent to about 2.7 methylene linkages in an alkyl chain where one methylene unit advances forward in $1.27 \AA$ towards the direction for the alkyl chain end on the basis of a C-C bond length of $1.54 \AA$ and the bond angle of $109.5^{\circ}$ (112 $113^{\circ}$ from Table 3-2).

To further elucidate the hydrophobic contribution of the lactone ring, the hydrophobicity of other cyclic moieties was investigated on aromatic and cyclohexyl compounds. The spacial distances of the benzene ring $[\mathrm{C}(1)$-symmetric $\mathrm{C}(4)$ (center-to- center) and the cyclohexyl ring ${ }^{23)}[\mathrm{C}(1)$ -the chair form end C (4) (center to center) are $3.8 \AA$ and $3.9 \AA$, respectively, from their structures. The width of the lactone ring, $2.4 \AA$, is comparable to the benzene-ring: 2.4 $\AA$, and cyclohexyl moiety: $2.5 \AA$. The lactone ring is polar and its surface area and surface charge are different from the cyclic hydrocarbons of benzene and cyclohexyl rings in referring to the chemical structure. However, the behavior

Table 4 Surface activity of spiculisporates at $30^{\circ} \mathrm{C}^{8,9)}$.

\begin{tabular}{cccc}
\hline & $\begin{array}{c}\mathrm{cmc} \\
\left(\times 10^{3} \mathrm{~mol} / \mathrm{l}\right)\end{array}$ & $\begin{array}{c}\gamma_{\mathrm{cmc}} \\
(\mathrm{mN} / \mathrm{m})\end{array}$ & $\begin{array}{c}\text { Foaming action } \\
\text { of 0.5\% soln. } \\
\text { (foam volume, } \mathrm{ml})\end{array}$ \\
\hline $\mathrm{S}-1 \mathrm{Na}$ & 3.5 & 32 & 22 \\
$\mathrm{~S}-2 \mathrm{Na}$ & 61 & 39 & 13 \\
$\mathrm{O}-1 \mathrm{Na}$ & 3.6 & 39 & - \\
$\mathrm{O}-2 \mathrm{Na}$ & 100 & 43 & - \\
O-3Na & 170 & 56 & 6 \\
SDS $^{* 1}$ & 8.1 & 36 & 237 \\
\hline
\end{tabular}

${ }^{{ }^{1}}$ Sodium dodecylsulfate (21).

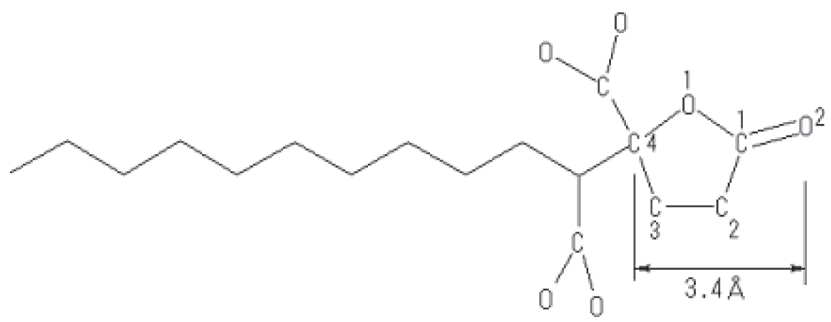

Fig. 5 The size of the lactone ring of spiculisporic acid. 
(due to the presence of the lactone ring in Table 4) is able to refer to them. This was from the additional prolongation effect of benzene ring which assumed methylene linkages to the $n$-alkylbenzene sulfonates. The hydrophobic contribution due to the insertion of the benzene ring into alkyl sulfonates is converted to the number of ca. 4 methylene linkages ${ }^{24)}$. Namely, the cmc of $p$ - $n$-decylbenzene sulfonate, $3.7 \times 10^{-3} \mathrm{~mol} / /\left(75^{\circ} \mathrm{C}\right)$, closely corresponds to $p$ - $n$-tetradecylsulfonate, $4.6 \times 10^{-3} \mathrm{~mol} / \mathrm{l}\left(80^{\circ} \mathrm{C}\right)$. This led to an empirical rule that benzene rings fit ca. 4 methylene linkages consisting of 3.0 methylene linkages $(3.8 \AA / 1.27 \AA)$ plus some more (ca. 1.0, probably by its width effect of benzene ring) molecular stacking.

Otherwise, the calculated hydrophobic contribution of the cyclohexyl moiety corresponds to 3.1 methylene linkages $(3.9 \AA / 1.27 \AA)$. The actual experimental data of the difference of $\Delta G^{\circ}$ (ad) [standard free energies of adsorption in water from the $(\mathrm{d} \gamma / \mathrm{dC})$ data] between cyclohexylalkanoic acid and $n$-alkanoic acid from the experimental data of $(\mathrm{d} \gamma / \mathrm{dC})^{25)}$, is equivalent to ca. 4.0 methylene linkages per cyclohexyl moiety. Namely, $\Delta G^{\circ}$ (ad) of $\omega$-cyclohexylbutanoic acid, $-25.9 \mathrm{kJmol}^{-1}$, is equivalent to that of $n$-octanoic acid, $-25.6 \mathrm{~kJ} \cdot \mathrm{mol}^{-1}$. So, the actual experimental results showed 4.0 methylene linkages / cyclohexyl moiety. The difference, $+0.9(4.0-3.1)$, may be caused by its width effect, which enhances the molecular aggregation due to its chair-type-conformation. The additional hydrophobic effects of benzene $(+1.0)$ and cyclohexane $(+0.9)$ seem to be attributed to wider hydrophobic atmospheres than those of straight alkyl chains owing to the hydrophobic hydration ${ }^{26)}$. The lactone ring must have the same hydrophobic effect like ca. + 1.0, and may correspond to 3.7 methylene linkages / lactone ring.

3.2.2 The role of lactone-ring ( $\gamma$-butanolide) as the hydrophobic moiety of sodium spiculisporates

Both of the lactone ring and $n$-undecyl moieties of spiculisporates are divided into two parts at C (5) (Fig. 1) with the hydrophilic carboxylate (s) serving as the polar head (s). Such di-nonpolar-type surfactants show higher cmc and lower $\gamma_{\mathrm{cmc}}$ values than those of straight alkyl chain bearing (and sole hydrophilic terminal) surfactants according to Hartley effect ${ }^{27,28)}$. However, lower $\mathrm{cmc}$ and lower foaming actions of S-1Na than O-1Na $\left[\left(\mathrm{CH}_{3}\left(\mathrm{CH}_{2}\right)_{9} \mathrm{CH}\right.\right.$ $(\mathrm{COOH}) \mathrm{C}(\mathrm{COOH})(\mathrm{OH}) \mathrm{CH}_{2} \mathrm{CH}_{2}-$ as the hydrophobic moiety] do not follow Hartley effect. The $\gamma_{\mathrm{cmc}}$ lowering of $\mathrm{S}-1 \mathrm{Na}$ follows the effect. The cmc decrease of S-1Na compared with that of O-1Na must be ascribed to the existence of free carboxylic moieties: one in $\mathrm{S}-1 \mathrm{Na}$ as is illustrated in Fig. 1, and two in O-1Na as in Fig. 1. Namely, the contribution of intermolecular hydrogen bonds like Fig. 4, are postulated for assisting the formation of hydrophobic core of the micelle ${ }^{26)}$. It is an evidence that the cmc value of S-1Na (one free $\mathrm{COOH}$ ) is considerably lower (one order small) than that of $\mathrm{S}-2 \mathrm{Na}$ (no free $\mathrm{COOH}$ ). Otherwise, weak ionic dissociations of double $\mathrm{COOH}$ moieties of S-1Na may affect its lower cmc than O-1Na. Furthermore, liquid crystallinity of aqueous solutions of branched alkyl derivatives of S-acid and $\mathrm{O}$-acid salts ${ }^{29)}$ may cause the different behavior. The latter presumption is encouraged by facts of the formation of lamellar liquid crystal in dialkyl-type surfactants like Aerosol $\mathrm{OT}^{30-32)}, \alpha$-sulfofatty acid ester salts ${ }^{33)}$, and so on. The above mentioned two effects may overlap themselves. So, it is suggested that $\mathrm{S}-1 \mathrm{Na}$ does not show the characteristic of the di-nonpolar-type surfactants.

The hydrophobic effectiveness of S-1Na and S-2Na, along with $\mathrm{O}-1 \mathrm{Na}, \mathrm{O}-2 \mathrm{Na}$, and O-3Na were compared to the surface activities of fatty acid soaps. S-1Na is summed up as a branched $\mathrm{C}_{15}$ carboxylate (branched $\mathrm{C}_{16}-\mathrm{Na}$ ) $[(n$-undecyl + side ca. 4 methylene linkages (lactone ring) $]$ from the concept in the section 3.2.1 (last part), and O-1Na as a kind of linear $\mathrm{C}_{14}$ carboxylate $\left(\mathrm{C}_{15} \mathrm{Na}\right)$ on the basis of their cmc values, ie. S-1Na: $3.5 \times 10^{-3} \mathrm{~mol} / \mathrm{L}\left(30^{\circ} \mathrm{C}\right)$ and $\gamma_{\text {cmc }}: 32$ $\mathrm{mN} / \mathrm{m}\left(30^{\circ} \mathrm{C}\right)$, and $\mathrm{O}-1 \mathrm{Na}: 3.6 \times 10^{-3} \mathrm{~mol} / \mathrm{L}\left(30^{\circ} \mathrm{C}\right)$ and $\gamma_{\mathrm{cmc}}$ : $39 \mathrm{mN} / \mathrm{m}\left(30^{\circ} \mathrm{C}\right)$. Those of Na tetradecanoate $\left(\mathrm{C}_{14}-\mathrm{Na}\right): \mathrm{cmc}$ $6.8 \times 10^{-3}\left(17 \sim 80^{\circ} \mathrm{C}\right)^{24)}$ or $2.9 \times 10^{-3} \mathrm{~mol} / \mathrm{L}\left(70^{\circ} \mathrm{C}\right)^{34)}$, and $\gamma_{\mathrm{cmc}} 33.2 \mathrm{mN} / \mathrm{m}\left(70^{\circ} \mathrm{C}\right)^{34)}$; K tetradecanoate $\left(\mathrm{C}_{14}-\mathrm{K}\right)$ : cmc 6.6 $\times 10^{-3} \mathrm{~mol} / /\left(25^{\circ} \mathrm{C}\right)^{24)}$; Na hexadecanoate $\left(\mathrm{C}_{16}-\mathrm{Na}\right): \mathrm{cmc} 3.0$ $\times 10^{-3} \mathrm{~mol} / \mathrm{L}\left(70^{\circ} \mathrm{C}\right)^{24)}$ and $\gamma_{\mathrm{cmc}} 31.4 \mathrm{mN} / \mathrm{m}\left(70^{\circ} \mathrm{C}\right)^{34)} ; \mathrm{K}$ hexadecanoate $\left(\mathrm{C}_{16^{-}} \mathrm{K}\right)$ : cmc $1.8 \times 10^{-3} \mathrm{~mol} / \mathrm{L}\left(35^{\circ} \mathrm{C}\right)^{24)} ; \mathrm{Na}$ laurate $\left(\mathrm{C}_{12}-\mathrm{Na}\right)$ : cmc $3.6 \times 10^{-2} \mathrm{~mol} / \mathrm{L}\left(20^{\circ} \mathrm{C}\right)^{24)}$ or $2.1 \times 10^{-2}$ $\mathrm{mol} / \mathrm{L}\left(70^{\circ} \mathrm{C}\right)^{34)}$ and $\gamma_{\mathrm{cmc}} 36.1 \mathrm{mN} / \mathrm{m}\left(70^{\circ} \mathrm{C}\right)^{34)}$ are recorded. Then, $\mathrm{S}-1 \mathrm{Na}$ is nearly equivalent to $\mathrm{C}_{16}-\mathrm{Na}$ of straight chain soaps. The cmc of $\mathrm{O}-1 \mathrm{Na}$ is like $\mathrm{C}_{12}-\mathrm{Na} \sim \mathrm{C}_{14}-\mathrm{Na}$, despite of a rather higher $\gamma_{\text {cmc. }}$. This must be attributed to a less efficient adsorption of O-1Na at the air-water interface owing to carry double $\mathrm{COOH}$ moieties.

Otherwise, it is known that the cmc values of cyclic alkyl linked surfactants generally correspond to $3 / 4$ of straight alkyl ones ${ }^{27)}$. Applying this rule to $\gamma$-butanolide, it corresponds to ca. 4 methylene linkages, $[5$ members $\times(3 / 4)]$. The behavior of the hydrophobic and low foaming properties of the lactone-carrying surfactant concerned (Table 5) is comparable to those of lactonic sophorolipid ${ }^{17)}$. Consequently, S-1Na, a branched (lactone ring and $n$-undecyl moieties) $\mathrm{C}_{15}-\mathrm{Na}$, behaved like the straight chain hexadecanoate $\left(\mathrm{C}_{16}-\mathrm{Na}\right)$ in the surface active behavior.

On the other hand, the polar head numbers of surfac$\operatorname{tants}^{35,36)}$ much affect their surface activities. Shinoda ${ }^{35)}$ investigated on the dependency of cmc values of fatty acid soaps on the polar head (carboxylates) numbers as followed; $\mathrm{C}_{15} \mathrm{H}_{31} \mathrm{COOK}: 1.6 \times 10^{-3} \mathrm{~mol} / \mathrm{L}, \mathrm{C}_{14} \mathrm{CH}-(\mathrm{COOK})_{2}: 1.7$ $\times 10^{-2}, \mathrm{C}_{12} \mathrm{CH}(\mathrm{COOK}) \mathrm{CH}(\mathrm{COOK})_{2}: 3.4 \times 10^{-2}$ and $\mathrm{C}_{14} \mathrm{CH}$ $(\mathrm{COOK}) \mathrm{CH}(\mathrm{COOK})_{2}: 1.2 \times 10^{-2} \mathrm{~mol} / \mathrm{l}\left(25^{\circ} \mathrm{C}\right)$. The results described herein seem to roughly follow the same trend as shown in Table 4.

As shown in Table 5, it is obvious that the shorter reaction time and smaller particle size (s) in the emulsion polymerization of $\mathrm{S}-1 \mathrm{Na}$ and $\mathrm{S}-2 \mathrm{Na}^{11)}$ are directly related to 
Table 5 Emulsion polymerization, dispersing action for $\mathrm{TiO}_{2}$, and calium ion sequestration of sodium spiculisporates ${ }^{8,11}$.

\begin{tabular}{|c|c|c|c|c|}
\hline & \multicolumn{2}{|c|}{ Emulsion polymerization $^{* 1}$} & \multirow{2}{*}{$\begin{array}{l}\text { Dispersing action }(\%) \\
\text { for } \mathrm{TiO}_{2}{ }^{* 2}, 0.1 \% \text { soln. }\end{array}$} & \multirow{2}{*}{$\begin{array}{l}\text { Ca ion sequestration } \\
\qquad\left(\mathrm{mg} \mathrm{CaCO}_{3} / \mathrm{g}\right)\end{array}$} \\
\hline & $\begin{array}{c}\text { Time of polymz. } \\
\text { (min) }\end{array}$ & $\begin{array}{c}\text { Particle size } \\
3.0 \% \text { soln. }(\mathrm{nm})\end{array}$ & & \\
\hline $\mathrm{S}-1 \mathrm{Na}$ & 45 & 500 & 0 & 4.6 \\
\hline $\mathrm{S}-2 \mathrm{Na}$ & 40 & 1480 & 0 & 10.6 \\
\hline $\mathrm{O}-3 \mathrm{Na}$ & 80 & 2532 & 74 & 49 \\
\hline Water & - & - & 16 & - \\
\hline
\end{tabular}

${ }^{{ }^{1} 1}$ Copolymerization of ethyl acrylate and methyl methacrylate by using spiculisporates.

${ }^{* 2}$ Rutile-type titan dioxide.

larger solubilizing and emulsifying activities as the characteristics of straight-chain bearing surfactants. On the other hand, O-3Na shows a larger dispersing action in rutile titanium dioxide reflecting the large stabilizing action giving prosperous electric charges onto the polar surface of titanium dioxide. The large calcium ion sequestration action of $\mathrm{O}-3 \mathrm{Na}$ is parallel to the large dispersing actions in titanium dioxide. The large $\mathrm{pH}$ buffering action of $\mathrm{O}-3 \mathrm{Na}^{8)}$ is also attributed to the triple polar heads.

Thus, spiculisporic acid exerts a functional conversion of the surface activity depending on the environmental changes, and has a unique chemical and molecular structure due to its double carboxylic moieties and a $\gamma$-butanolide, which is produced by an enzymatic reaction of lauryl CoA with 2-ketoglutaric acid of the TCA cycle of a kind of fungus ${ }^{12)}$. The microorganism may make use of spiculisporates for its own preservation and growth (high acidity, surface activity), and migration (precipitates) in its growing surroundings.

\section{CONCLUSION}

(1) The molecular structure of microbially produced spiculisporic acid was investigated by means of $\mathrm{X}$-ray crystallographic analysis. The crystal is orthorhombic, and the molecules form intermolecular networks linked by hydrogen bonds around their polar carboxylic moieties. The $n$-undecyl chain formed in an all-trans conformation, and the connecting lactone ring was almost in the straight alignment with $n$-undecyl chain. The molecules penetrated with each other in in an interdigitated manner in layers at $137^{\circ}$.

(2) It was confirmed that the lactone ring ( $\gamma$-butanolide) in sodium spiculisporates behaved as a hydrophobic moiety in their surface active properties with $n$-undecyl chain. Furthermore, the lactone ring shares the hydrophobicity of about 4 methylene linkages / molecule, and contributes to both of the lowerings of critical micelle concentration (cmc) and $\gamma_{\text {cmc }}$ (surface tension at the cmc) through their surface activity. This is a useful function for surfactants.

(3) Sodium spiculisporates $(\mathrm{S}-1 \mathrm{Na})$ is a kind of branched (lactone ring and $n$-undecyl ) $\mathrm{C}_{16}-\mathrm{Na}$ (sodium hexadecanoate) from its hydrophobic structure, and behaved like the straight-chain sodium pentadecanoate. Sodium salts of the lactone-cleaved derivative of spiculisporic acid (O-acid) showed large dispersing and calcium ion sequestration actions due to their plural polar heads.

\section{References}

1) Goto, M. Crystal structure and polymorphism of normal saturated fatty acids. J. Jpn. Oil Chem. Soc. 36, 909-919 (1987).

2) Goto, M.; Kozawa, K.; Uchida, T. The Crystal structure of the $\beta_{1}^{\prime}$ form of optically active $\alpha$-monostearin. Bull. Chem. Soc. Jpn. 51, 70-74(1978).

3) Goto, M.; Kodali, D. R.; Small, D. M.; Honda, K.; Kozawa, K.; Uchida. T. Single crystal structure of a mixedchain triacylglycerol: 1,2-dipalmitoyl-3-acetyl-sn-glycerol. Proc. Natl. Acad. Sci. USA. 89, 8083-8086 (1992).

4) XU, G.; Okuyama, K.; Shimomura, M. Molecular and Crystal structure of azobenzene-containing amphiphile, $\mathrm{C}_{6} \mathrm{AzoC}_{10} \mathrm{~N}^{+} \mathrm{Br}^{-}$. Bull. Chem. Soc. Jpn., 64, 248251 (1991).

5) Abe, Y.; Fujiwara, M.; Harada, K. Crystal Structure of Sugar-based Amphiphiles. Hyomen 38, 157-174 (2000).

6) Ishigami, Y.; Goto, M. The Crystal structure and the fluorescent properties of curcumin. J. Jpn. Soc. of Colour Material (SHIKIZAI) 72, 71-77(1999).

7) Ishigami, Y.; Goto, M.; Takizawa, Y.; Shinoyama, H. Xylosyl Stacking structure of $n$-heptyl $\beta$-D-xyloside in the hydrous crystal. J. Oleo Sci. 50, 555-560 (2001).

8) Ishigami, Y.; Yamazaki, S.; Gama, Y. Surface active 
properties of biosoap from spiculispric acid. J. Colloid and Interface Sci. 94, 131-139 (1983).

9) Ishigami, Y.; Yamazaki, S. Surface active properties and application of polycarboxylic biosurfactant. Bull. Natl. Chem. Lab. 80, 231-237(1985).

10) Fujii, T.; Hashimoto, T.; Yoshimura, M.; Ishigami, Y. Biodetergent. I. Detergency performance of sodium and alkylamine salts of spiculisporic acid as polycarboxylic biosurfactant. J. Jpn. Oil Chem. Soc. 39, 1040-1044(1990).

11) Yamazaki, S., Ishigami, Y., Gama, Y. Copolymerization of ethyl acrylate and methyl methacrylate by using biosoap with polyfunctional groups. Kobunshi Ronbunshu 40, 569-574(1983).

12) Tabuchi, T.; Nakamura, I.; Kobayashi, T. Accumulation of the open-ring acid of spiculisporic acid by Penicillium spiculisporum in shake culture. J. Ferment. Technol. 55, 37-42(1977).

13) Osman, M., Ishigami, Y., Ishikawa, K., Ishizuka, Y., Holmsen, H. Dynamic transition of $\alpha$-helix to $\beta$-sheet structure in linear surfactin correlating to critical micelle concentration. Biotechnology Letters 16, 913918(1994).

14) Osman, M., Hoiland, H., Holmsen, H., Ishigami, Y. Tuning micelles of a bioactive heptapeptide biosurfactant via extrinsically induced conformational transition of surfactin assembly. J. Peptide Sci. 4, 449-458(1998).

15) Davila, A-M.; Marchal, R.; Vandecasteele, J-P. Kinetics and balance of a fermentation free from product inhibition: sophorose lipid production by Candida bombicola. Appl. Microbiol. Biotechnol. 38, 6-11(1992).

16) Kimura, Y.; Inoue, S. Biosurfactant produced by an yeast Sophorolipid. in Biosurfactant (Yasuda, H.; Aihara, K.; Ueda, S.; Nozaki, M. ed.), Science Forum. Tokyo. pp. 455-464 (1990).

17) Hirata, Y.; Ryu, M.; Igarashi, K.; Nagatsuka, A.; Furuta, T.; Kanaya, S.; Sugiura, M. Natural synergism of acid and lactone type mixed sophorolipids in interfacial activities and cytotoxicities. J. Oleo Sci. 58, 565-572 (2009).

18) Ishigami, Y. Biosurfactant. Kagaku Kogyo 41 (9), 756765 (1990).

19) Kurita, S.; Sirisatta, S.; Kitagawa, E.; Momose, Y.; Akama, K.; Ishigami, Y.; Iwahashi, H. New method for the assessment of biological effect by surfactants using yeast DNA microarray. J. Oleo Sci. 53, 387-398 (2004).

20) Tabuchi, T.; Nakamura, I.; Higashi, E.; Kobayashi, H. Factors affecting the production of the open-ring acid of spiculisporic acid by Penicillium spiculisporum. J. Ferment. Technol. 55, 43-49 (1977).

21) Altomare, A.; Cascarano, G.; Giacovazzo, C.; Guagliar- di, A. J. Appl. Cryst. 27, 435(1994).

22) Mackay, S.; Gilmore, C. J.; Edwards, C.; Stuart, N.; Shankland, N. in Version 6.3. University of Glasgow, Scotland (1995).

23) Varughese, K. I.; Chacko, K. K. The crystal and molecular structure of 1-aminocyclohexanecarboxylic acid, Acta Cryst. B31, 866-868(1975).

24) Hirano, J. II-2 Structure of surfactants in Kaimenkasseizai Benran (Handbook of Surfactants) (Nishi, I.; Imai, K; Kasai, M eds.), Sangyo Tosho, Tokyo. pp. 127-130 (1960).

25) Skauge, A.; Spitzer, J. J. Surface tension and micellization of $\omega$-cyclohexylalkanoic acids and their sodium salts. J. Phys. Chem. 87, 2398-2401 (1983).

26) Tamaki, K. Hydrophobic bonds and interfacial phenomena. Hyomen 3, 527-533 (1965).

27) Aizawa, M.; Suzuki, S. I-1 Structures and Properties. in Kaimenn Kasseizai (Surfactants)-Properties/Application/ Chemical Ecology-(Kitahara, A.; Tamai, Y.; Hayano, S.; Hara, I. eds.), Kodansya, Tokyo, pp. 10-16 (1991).

28) Sasaki, T. Molecular structure and surface activity of surface active substance. J. Jpn. Oil Chem. Soc. 17, 116-124 (1968).

29) Ishigami, Y.; Gama, Y.; Yamazaki, S. The pH-dependent conversion of molecular aggregation of polycarboxylic biosurfactant. J. Jpn. Oil Chem.Soc. 36, 490-495 (1987).

30) Park, D.; Rogers, R. W.; Toft, R. W.; Winsor, P. A. The structure of micellar solutions of ionic amphiphiles: the lamellar phase. X-ray diffraction measurements with Aerosol OT/water system. J. Colloid and Interface Sci. 32, 81-89 (1970).

31) Ungar, G.; Tomasic, V.: Xie, F.; Zeng, X-B. Structure of liquid crystalline Aerosol OT and its alkylamine salts. Langmuir 25, 1067-1072(2009).

32) Kunieda, H.; Shinoda, K. Solution behavior of ionic surfactants containing two long -chain alkyl groups. $J$. Jpn. Oil Chem. Soc. 27, 417-424(1978).

33) Fujiwara, M; Ohbu, K.; Aqueous solution properties of $\alpha$-sulfofatty acid ester salts. Hyomen 33, 65-70 (1995).

34) Powney, J.; Addison, C. C. The surface activity and critical concentrations of aqueous solutions of saturated soaps under conditions of suppressed hydrolysis. Trans. Faraday Soc. 34, 372-377(1938).

35) Shinoda, K. The critical micelle concentration in aqueous solutions of potassium alkane tricarboxylates. $J$. Phys. Chem. 60, 1439-1440(1956).

36) Yasuda, M.; Ikeda, K.; Esumi, K.; Meguro, K. Effect of head group size on aqueous properties of $\alpha, \omega$-type surfactant. Langmuir 6, 949-953 (1990). 